\title{
De OESO, BEPS en de impact voor het fiscale stelsel van Curaçao
}

\author{
Mr. G.D. Rekwest E Prof dr. P. Kavelaars*
}

\section{Inleiding}

De afgelopen jaren is door de Organisatie voor Economische Samenwerking en Ontwikkeling (OESO) het zogenoemde 'BEPS-project' ontwikkeld waarbij 'BEPS' staat voor de strijd tegen 'Base Erosion and Profit Shifting'. Dit project is wereldwijd uitgerold en dwingt landen ertoe hun fiscale stelsels te ontdoen van regelingen die kunnen leiden tot BEPS. Er zijn inmiddels meer dan 130 landen die het initiatief onderschrijven; zij nemen daarmee deel aan het zogenoemde 'All Inclusive Framework'. Aruba en Curaçao maken daar net als Nederland (inclusief Bonaire, Sint Eustatius en Saba) deel van uit. De Europese Unie (EU) heeft het OESO-initiatief overgenomen en ook nog aangevuld met eigen elementen. ${ }^{1}$

Een van de onderdelen van BEPS is dat landen geen zogenoemde 'schadelijke belastingregelingen' meer mogen hebben op straffe van een plaats op de grijze of zwarte lijst. In dat kader hebben Aruba en Curaçao hun fiscale stelsels de afgelopen jaren op een aantal punten moeten aanpassen. In dit artikel gaan wij in op de door Curaçao doorgevoerde wijzigingen. In Curaçao heeft de aanpassing van de wetgeving in een aantal fasen plaatsgevonden, onder andere omdat de OESO en de EU niet geheel op één lijn zaten ten aanzien van de beoordeling of de indertijd voorgenomen wijzigingen adequaat waren. Ingaande 2020 is het fiscale stelsel zowel in overeenstemming met de voorwaarden van de OESO als met de door de EU gestelde voorwaarden. Daartoe is laatstelijk - per 1 januari 2020 - de Landverordening belastingherziening 2019 in werking getreden. ${ }^{2}$ Met de belastingherziening heeft Curaçao op aandringen van Europese Code of Conduct Group (EU COCG) zijn belastingwetgeving op een aantal punten aangepast om te kunnen voldoen aan de minimumeisen van de EU COCG en de Forum for Harmful Tax Practices (FHTP) van de OESO. Curaçao had overigens in 2018 onder druk van de OESO al een belastingherziening doorgevoerd, doch deze was met name door de EU op één onderdeel als onvoldoende aangemerkt. ${ }^{3}$ Bovendien heeft Curaçao ook op eigen initiatief tussentijds gesleuteld aan de wijzigingen. Deze

* Mr. G.D. Rekwest is promovenda aan de University of Curaçao en de Erasmus Universiteit Rotterdam. Prof. dr. P. Kavelaars is hoogleraar Fiscale Economie aan de Erasmus Universiteit Rotterdam.

1 Op 26 april 2018 introduceerde de EU (ECOFIN) een nieuwe standaard voor 'Tax Good Governance', waarin naast transparantie en informatie-uitwisseling ook de implementatie van de vier minimumstandaarden van de BEPS is opgenomen.

2 Landsverordening belastingherziening 2019, PB 2019, nr. 92.

3 Landsverordening van de 27ste december 2018 tot wijziging van de Algemene landsverordening Landsbelastingen, de Landsverordening op de winstbelasting 1940, de Landsverordening economische zones 2000, de Landsverordening omzetbelasting 1999, de Successiebelastingverordening 1908 en de Landsverordening reparatie preferentiële belastingregimes (Landsverordening belastingherzieningen 2018), PB 2018, nr. 83. 
'wijziging op wijziging' zorgde niet alleen voor een onoverzichtelijk traject in fiscale wetgeving, maar bracht ook onzekerheid voor de burgers en investeerders met zich. ${ }^{4}$ Met de nu definitieve wetgeving per 1 januari 2020 zijn die onduidelijkheden en onzekerheden in principe weggenomen. Terzijde zij opgemerkt dat in dit verband verder van belang is dat per ultimo 2019 ook het twintig jaar bestaan hebbende overgangsregime voor offshore vennootschappen tot een einde is gekomen. Dit fiscaal aantrekkelijke regime is indertijd onder druk van Nederland afgeschaft.

In het kader van het zoeken naar oplossingen voor de door de OESO en de EU vereiste aanpassingen van de diverse fiscale faciliteiten, speelde een rol in hoeverre één of meer fiscaal aantrekkelijke faciliteiten deel zouden kunnen blijven uitmaken van de fiscale regelgeving en onder welke voorwaarden. Daarmee ontstond voor de wetgever een complex probleem dat nu dus is opgelost in de huidige wetgeving. Overigens is er nog een ander traject dat in het BEPS-kader inmiddels is opgestart en dat betreft de aanpassing van de Belastingregeling voor Nederland en Curaçao (BRNC); aan dat traject besteden we geen aandacht. ${ }^{5}$ De kern van ons artikel gaat over de nieuwe fiscale regels op Curaçao zoals die ingaande 2020 definitief zijn ingevoerd.

De opbouw van deze bijdrage is als volgt. In paragraaf 2 gaan we in op de ratio van de belastingherziening 2019. In de opvolgende paragrafen zoomen wij in op de verschillende elementen van de aanpassingen. Zo bespreken wij in paragraaf 3 het nieuwe territorialiteitssysteem, waarna in paragraaf 4 de nieuwe preferentiële regimes aan de orde komen. In paragraaf 5 gaan wij in op de mogelijke effecten van belastingfaciliteiten. Wij besluiten in paragraaf 6 met enkele conclusies.

\section{OESO, EU en BEPS}

De hierna te bespreken door Curaçao doorgevoerde herzieningen van het fiscale stelsel vloeien zoals in paragraaf 1 is aangegeven voort uit het door de OESO ingezette BEPStraject. De OESO heeft daar in 2012 een start mee gemaakt toen duidelijk werd dat vooral het internationale bedrijfsleven kans zag om met name winstbelasting op vrij grote schaal te beperken of zelfs te ontwijken. De belangrijkste 'instrumenten' van de multinationals waren de dispariteiten tussen fiscale stelsels van landen waar zij actief zijn en het gebruiken van verdragen ter voorkoming van dubbele belasting teneinde zogenoemde 'non-belasting' te effectueren. Het initiatief van de OESO is al spoedig opgepakt door de EU. Deze laatste kan uiteraard alleen tot regelgeving komen die de lidstaten raakt, maar gebleken is dat een groot aantal regels die zijn ontwikkeld ook in de verhouding tot derde landen kan worden toegepast. Bovendien hanteert de EU het vereiste van een good tax governance: landen die geen adequaat belastingstelsel hebben worden op een grijze of zwarte lijst gezet. Ook de OESO hanteert deze laatste methodiek: landen in de wereld die geen 'normaal' fis-

4 Advies betreffende de ontwerplandsverordening belastingherziening 2019, 6 november 2019, 123/2019SER.

5 Dit betreft wijzigingen in verband met het in 2017 aangepaste OESO-modelverdrag. Het belangrijkste onderdeel van de aanpassing betreft de wijziging van de antimisbruikbepaling en overigens de invoering van diverse specifieke antimisbruikbepalingen. 
caal stelsel hebben en belastingontwijking mogelijk maken komen op een grijze of zwarte lijst terecht. Enigszins vervelend is in dit verband wel dat de EU en de OESO niet precies dezelfde criteria hanteren. Dit heeft ook Curaçao enigszins opgebroken doordat de OESO op enig moment akkoord is gegaan met de wijzigingen in het fiscale stelsel, terwijl de EU niet volledig akkoord was. ${ }^{6}$ Dit heeft uiteindelijk tot nadere aanpassingen geleid, met name uitmondend in het in paragraaf 3 uiteengezette territoriale stelsel.

Terug naar de OESO. Deze organisatie kent 'slechts' 36 leden en heeft geen wetgevende bevoegdheid. Daarmee lijkt diens positie zwak. Het tegendeel blijkt echter inmiddels waar: het merendeel van de landen in de wereld (momenteel meer dan 130) heeft zich bij het pakket maatregelen dat de OESO in 2015 publiceerde ${ }^{7}$ aangesloten en daarmee het in de inleiding reeds genoemde All Inclusive Framework van de OESO toegezegd te implementeren in de nationale regelgeving. De landen zijn daar momenteel druk mee doende. Het All Inclusive Framework bestaat in feite uit vijftien actiepunten die tezamen het BEPS-project vormen. Het gaat te ver dat hier uit te werken. ${ }^{8}$ We beperken ons daarom tot enkele hoofdpunten. Voor de nabije toekomst is actiepunt 1 van belang; dit onderdeel is nog in ontwikkeling en beoogt tot aanpassingen in fiscale wetgeving en belastingverdragen te komen met betrekking tot de digitale economie. Deze digitale economie vereist ingrijpende fiscale wijzigingen die evenwel zodanig complex zijn dat daar nog geen oplossing voor is gevonden.

Een tweede zeer belangwekkend onderdeel heeft betrekking op het opnemen van antimisbruikbepalingen in de fiscale wetgeving en in belastingverdragen. Daarbij is er vooral veel discussie (geweest) of dit de vorm zou moeten krijgen van specifieke antimisbruikbepalingen of algemene antimisbruikbepalingen. De OESO en de meeste landen opteren voor de laatste variant. Voor belastingplichtigen betekent dit in het algemeen veel meer (rechts)onzekerheid omdat algemene antimisbruikbepalingen de vorm hebben van meer vage criteria.

Een derde zeer relevant onderdeel betreft de invoering van een min of meer alomvattend stelsel van automatische informatie-uitwisseling tussen landen (Common Reporting Standard ofwel CRS) dat voorziet in het renseigneren van informatie over allerlei soorten inkomsten die in het ene land opkomen en toekomen aan een belastingplichtige die in een ander land woont of is gevestigd. Curaçao heeft deze CRS inmiddels ook uitgerold, evenals een specifieke variant daarvan, te weten de Country-by-Country-wetgeving $(\mathrm{CbC})$ die grote multinationals verplicht allerlei informatie te verstrekken over internationale goederen- en dienstenstromen, de daarmee behaalde winsten en de (onderbouwing van de) prijzen (zogenoemde 'verrekenprijzen') van die goederen en diensten.

6 Brief van 1 februari 2019 van de Europese Raad, nr. 5981/19, 'Letters seeking commitment on the replacement by some jurisdictions of harmful preferential tax regimes with measures of similar effect'.

7 Alle actieplannen en ook de voortrajecten daartoe zijn integraal te vinden op de site van de OESO. Het betreft zeer omvangrijke teksten die tot stand zijn gekomen na uitvoerige consultaties welke eveneens zijn te vinden op de website van de OESO. Het enige actiepunt dat nog geen definitieve vorm heeft betreft nummer 1 dat betrekking heeft op de gevolgen van de digitale economie voor de belastingheffing.

8 Zie hierover uitvoeriger P. Kavelaars, Internationale fiscaliteit in transitie (oratie Curaçao), Amsterdam: NL Fiscaal 2017. 
Als laatste onderdeel van het BEPS-traject noemen we de zogenoemde 'bestrijding van de schadelijke belastingregimes' (harmfull tax competition), met name in de EU ook wel bekend als de Code of Conduct. Het gaat er hierbij om dat landen geen fiscale stelsels of regelingen mogen toepassen die kort gezegd de concurrentie verstoren door buitenlandse ondernemingen te beperken in hun mogelijkheden en binnenlandse ondernemingen juist gunstiger te behandelen. Maar het is breder: preferentiële regimes die een land aantrekkelijk kunnen maken voor buitenlandse investeerders zijn in het algemeen niet toegestaan. Slechts algemene fiscale regelingen zijn aanvaardbaar. Zo zijn specifieke tarieven voor bepaalde activiteiten vaak niet toegestaan tenzij aan zeer stringente voorwaarden is voldaan. Een generiek laag winstbelastingtarief is veelal wel toegestaan. In de EU heeft Hongarije bijvoorbeeld een winstbelastingtarief van 'slechts' $9 \%$ hetgeen niet op enig bezwaar stuit. De strijd tegen harmfull tax competition heeft Nederland enkele jaren geleden genoodzaakt het regime van de innovatiebox aan te passen. Voor Curaçao heeft het geleid tot de aanpassing van diverse regimes waar dit artikel betrekking op heeft. In de volgende paragrafen wordt daarop ingegaan.

Ter afronding van deze OESO- en EU-initiatieven die de afgelopen jaren zijn uitgerold kan de vraag opkomen of daarmee het eindstation is bereikt. Daar ziet het niet naar uit. De OESO ontwikkelt momenteel plannen die onder andere bestaan uit verdergaande antimisbruikbepalingen, een verschuiving van heffing naar zogenoemde 'marktstaten' (ofwel staten waar de afzet plaatsvindt in plaats van staten waar de productie plaatsvindt) en tot slot naar een systeem waarin elk land een minimale belastingheffing moet toepassen. Of, en zo ja wanneer, dit allemaal wordt geëffectueerd is momenteel nog (zeer) onzeker.

\section{Territorialiteitssysteem}

Voor ondernemingen die internationaal opereren is uiteraard niet alleen het fiscale stelsel relevant in hun thuisstaat (vestigingsstaat), maar ook dat van de andere landen waar zij actief zijn. Internationaal kan dit gemakkelijk tot dubbele heffing leiden. Enerzijds omdat wereldwijd het fiscale uitgangspunt wordt gehanteerd dat het vestigingsland belasting heft over de wereldwinst van het concern (woonplaatsbeginsel) en anderzijds omdat landen waar ondernemingsactiviteiten plaatsvinden de daarmee behaalde winst normaliter wensen te belasten (bronlandbeginsel). Het behoeft geen betoog dat toepassing van beide beginselen dubbele heffing veroorzaakt. Verdragen ter voorkoming van dubbele belasting beogen hierin te voorzien en hanteren daarbij als kernregel dat de bronstaat mag heffen en de vestigingsstaat een vrijstelling verleent. Nederland heeft een groot verdragennetwerk waarmee dat wordt geëffectueerd maar dat geldt niet voor Curaçao dat slechts één verdrag kent. ${ }^{9}$ Wil men bij afwezigheid van een verdrag buitenlandse winst vrijstellen dan kan dat eenzijdig gebeuren. Nederland en Curaçao doen dat bij (buitenlandse) dochtervennootschappen door ontvangen winstuitdelingen en vervreemdingswinsten op de aandelen in die buitenlandse dochters vrij te stellen onder de deelnemingsvrijstelling. Is sprake van een buitenlands filiaal zonder rechtsvorm (in fiscale termen een vaste inrichting) dan stelt

9 Met Noorwegen; daarnaast is er uiteraard nog wel de Belastingregeling voor het Koninkrijk (BRK) en de BRNC. 
Nederland een dergelijke winst vrij op basis van een objectvrijstelling (art. 15e Wet op de vennootschapsbelasting 1969). Dergelijke vrijstellingen zijn internationaal aanvaard en niet in strijd met de regels van de OESO en de EU. Omgekeerd betekent het natuurlijk ook dat winsten van activiteiten van buitenlandse investeerders op Curaçao door Curaçao mogen worden belast. Teneinde investeringen aan te trekken is het uiteraard aantrekkelijk om een fiscaal regime te kennen dat dergelijke in Curaçao behaalde winsten laag belast of vrijstelt. Evenwel leidt dat al snel tot harmfull tax competition. Bovendien is evident dat dit ook tot een ongelijke behandeling kan leiden tussen binnenlandse investeerders en buitenlandse investeerders indien de binnenlandse investeerders niet of een beperktere fiscale faciliteit krijgen. Het ingaande 2020 definitief afgeschafte offshore regime was typisch een vorm van harmfull tax competition en is onder druk van Nederland afgeschaft.

Het voorgaande geeft in feite de spagaat aan waar vele landen en zeker ook Curaçao zich in bevonden en veelal nog steeds in bevinden: hoe creëer ik een aantrekkelijk fiscaal regime voor met name buitenlandse investeerders, maar wordt voorkomen dat sprake is van strijdigheid met regels van de EU en de OESO inzake schadelijke belastingconcurrentie?

Wij zullen het voortraject tot het uiteindelijk ingaande 2020 in Curaçao ingevoerde regime niet bespreken maar alleen de daadwerkelijk ingevoerde regelgeving uiteenzetten. Het nieuwe regime wordt aangeduid als een territoriaal systeem. Dit territoriaal systeem faciliteert echter niet buitenlandse investeerders in Curaçao maar in Curaçao gevestigde ondernemingen voor zover die in het buitenland investeren. De oorspronkelijke opzet van de belastingherziening in 2018 was dat buitenlandse winst in de totale winst van een in Curaçao gevestigde ondernemer is begrepen en deze vervolgens wordt vrijgesteld. Deze opzet had wel de goedkeuring van de OESO maar niet die van de EU. Dat laatste is buitengewoon merkwaardig want een dergelijk systeem is internationaal bezien zeer gebruikelijk en wordt bijvoorbeeld ook in Nederland toegepast in de vorm van een objectvrijstelling voor buitenlandse winst. Wat daarvan zij, Curaçao heeft het systeem nu in die zin gewijzigd dat voortaan het object van heffing alleen bestaat uit de winst die wordt behaald in Curaçao. Daardoor hoeft de buitenlandse winst niet te worden vrijgesteld. Het uiteindelijke effect daarvan is in essentie volstrekt hetzelfde als de toepassing van een objectvrijstelling; evenwel is de EU akkoord met dit nu ingevoerde zogenoemde 'territoriale stelsel' - alleen winst behaald op het territorium van Curaçao - is belastbaar (art. 4 lid 4 Landsverordening op de winstbelasting 1940 (LWB 1940)). Voor de meeste activiteiten staat wel vast of deze in Curaçao plaatsvinden of daarbuiten, maar vooral voor dienstverlening kan dat wat complexer zijn. Er zijn richtlijnen gepubliceerd waarin nadere aanwijzingen zijn opgenomen wanneer sprake is van binnenlandse en buitenlandse winst. Beleggingsopbrengsten worden overigens altijd als binnenlandse winst aangemerkt. Als de vennootschap dus een rekening aanhoudt in het buitenland behoort de opbrengst tot de binnenlandse winst en is die dus belast. Zou dat niet het geval zijn dan zou de opbrengst doorgaans geheel onbelast blijven omdat op grond van de regels van internationaal belastingrecht zogenoemde "passieve inkomsten' in de regel alleen worden belast in het vestigingsland en niet in het land waar de opbrengsten opkomen.

Het territorialiteitsbeginsel brengt ook mee dat buitenlanders die ondernemingsactiviteiten verrichten in Curaçao daarvoor belast zijn. Dat is overigens niet anders onder 
andere beginselen: het in dezen meestal toegepaste bronlandbeginsel houdt namelijk in dat het land waar de bron is gelegen - in casu de feitelijke ondernemingsactiviteiten - heffingsbevoegd is over de daarmee gerealiseerde opbrengsten. Voorwaarde onder zowel het bronland- als het territorialiteitsbeginsel is dat een vaste inrichting aanwezig is. Is een dergelijke vaste inrichting niet aanwezig in Curaçao dan is ook geen sprake van onderworpenheid aan de winstbelasting. Het begrip 'vaste inrichting' is door de OESO gedefinieerd voor verdragstoepassing en in 2017 uitgebreid. Curaçao sluit daarbij aan.

Het zal duidelijk zijn dat in de winstbelasting op het hiervoor besproken punt geen sprake meer is van een schadelijk belastingregime. Ook het tarief - ongewijzigd 22\% - leidt daar niet toe. Wel is er voor winst behaald met bepaalde activiteiten een tarief van 3\%; daarbij wordt geen onderscheid gemaakt tussen binnenlandse ondernemers en buitenlandse ondernemers met activiteiten in Curaçao. In zoverre is er dus niets aan de hand. Maar niettemin is het wel opmerkelijk dat dit door de EU en de OESO is aanvaard. In het algemeen geldt namelijk de regel dat generieke lage tarieven in beginsel wel aanvaardbaar zijn, ${ }^{10}$ maar specifieke lage tarieven niet (alleen voor research and development (R\&D)-winsten maakt men wel een uitzondering). En van dit laatste is onmiskenbaar sprake.

De verdere meer technische uitwerking van de winstbelasting komt in de volgende paragraaf aan de orde.

\section{Nieuwe winstbelastingregimes}

\subsection{Inleiding}

Het nieuwe winstbelastingstelsel zoals dat per 1 januari 2020 op Curaçao is ingevoerd wordt gekenmerkt door grofweg drie elementen. Het eerste element betreft de introductie van een algeheel territoriaal systeem en is in de vorige paragraaf in grote lijnen aan de orde geweest. Hierop voortbordurend gaan we in paragraaf 4.2 in op de vraag wat onder winst uit binnenlandse onderneming moet worden verstaan. Het tweede element van het nieuwe stelsel betreft het verlaagde winstbelastingtarief van $3 \%$ voor specifieke activiteiten (par. 4.3). Het derde element is de uitbreiding van de reikwijdte van de Belastingfaciliteiten Investeringen (zie par. 4.4).

\subsection{Winst uit binnenlandse onderneming}

Met de invoering van een algeheel territoriaal systeem wordt met ingang van 1 januari 2020 enkel over lokale ondernemingswinst geheven. Het heffingsobject van de winstbelasting is derhalve alleen de winst die in Curaçao wordt behaald. Wat onder binnenlandse winst dient te worden verstaan, wordt nader uitgewerkt in de zogenoemde 'Richtlijnen bepaling binnenlandse winst'. ${ }^{11}$ Opmerkelijk is dat deze richtlijnen bij de inwerkingtreding van de belastingherziening 2019 niet in de Landsverordening waren opgenomen, maar in de memorie van toelichting zijn opgenomen. De Sociaal-Economische Raad (SER) heeft in zijn advies bij de ontwerp-landsverordening belastingherziening 2019 hier kritische kant-

10 Zo werd het (lage) algemene winstbelastingtarief van Ierland (12,5\%) in het OESO-rapport 'Harmful Tax Competition: An Emerging Global Issue' uit 1998 nog aanvaard.

11 MvT, nr. 3 bij de Landsverordening belastingherziening 2019, par. 2, Overzicht wijzigingen, p. 2-5. 
tekeningen bij geplaatst. In februari 2020 heeft de SER op verzoek van de Minister van Financiën advies uitgebracht over de invulling van het begrip 'binnenlandse winst' en de daarbij behorende richtlijnen. ${ }^{12}$ Volgens de richtlijnen, zoals vooralsnog opgenomen in de memorie van toelichting, gaat het om winst die wordt gegenereerd met activiteiten die worden verricht in Curaçao en met activa die zijn verbonden aan Curaçao. Als voorbeeld worden genoemd bedrijfsactiviteiten die verbonden zijn aan in Curaçao gelegen (onroerende) zaken of in Curaçao gebruikte rechten. Niet alleen winsten behaald met lokale commerciële, industriële en innovatieve activiteiten, maar ook bancaire diensten en inkomsten die buitenlandse vennootschappen behalen met behulp van een vaste inrichting op Curaçao worden aangemerkt als binnenlandse winst. Daarnaast worden beleggingsopbrengsten - zogenoemd 'passief inkomen' - nadrukkelijk tot de binnenlandse winst gerekend. Als gevolg van het ingevoerde territoriaal regime zijn ook de belastingfaciliteiten en vrijstellingen ten aanzien van de buitenlandse winst geschrapt. ${ }^{13}$ Als buitenlandse winst worden in ieder geval beschouwd: de winst van een buitenlandse vaste inrichting die een Curaçaose vennootschap houdt en transacties zoals bancaire diensten aan niet-inwoners en activiteiten die in het buitenland plaatsvinden.

\subsection{Specifieke activiteiten}

Naast de invoering van een algeheel territoriaal stelsel is per 1 januari 2020 een nieuw preferentieel regime geïntroduceerd voor specifieke activiteiten om de lokale arbeidskansen te verbeteren en de economie te stimuleren. Er is gekozen voor een aantal sectoren waarin Curaçao zich wil specialiseren. Enerzijds gaat het om nieuwe industrieën zoals call- en datacenters, alsmede IT-activiteiten, anderzijds betreft het een uitbreiding van bestaande industrieën, zoals scheepsbouw, vliegtuigonderhoud, fondsmanagement en administratie. Volgens de memorie van toelichting zijn de gemaakte keuzes voor de kwalificerende activiteiten 'te herleiden tot de visie en het integraal beleid van de regering. ${ }^{14}$ Het valt te betreuren dat in de parlementaire stukken de keuze voor deze activiteiten niet concreter is ingevuld en toegelicht. Voor deze specifieke activiteiten geldt op grond van artikel 15 lid 4 LWB 1940 niet het algemene winstbelastingtarief van 22\%, maar een verlaagd winstbelastingtarief van 3\%. 'Kwalificerende' activiteiten die zijn verricht door professionele dienstverleners zoals notarissen, advocaten, openbare accountants en fiscale adviseurs zijn uitgesloten van het verlaagde tarief van $3 \%$. De uitsluiting geldt tevens voor het optreden als directie van vennootschappen.

Als 'kwalificerende' activiteiten worden aangemerkt:

1 vliegtuig-en scheepsbouwactiviteiten;

2 gespecialiseerde bedrijfsondersteunende activiteiten: call-, service- of datacenters voor zover zij ondersteunende activiteiten verrichten aan een onderneming met een omzet van minimaal NAf 50 miljoen, accounting en auditing, humanresourceactiviteiten, monitoren gezondheids- en milieunormen, informatietechnologiediensten, public-

12 SER Curaçao, Advies betreffende het Landsbesluit, houdende algemene maatregelen, trekkende tot wijziging van het Landsbesluit winstbelasting, ref.nr. 008/2020-SER.

13 In dit kader zijn onder meer art. 1A lid 1 onderdeel c jo. art. 8 jo. art. 12 LWB 1940 vervallen.

14 MvT, nr. 3 bij de Landsverordening belastingherziening 2019, p. 12. 
relationsactiviteiten, juridische diensten, fiscale werkzaamheden en algemene diensten van administratieve aard;

3 veembedrijf (opslag) en gerelateerde dienstverlening;

4 diensten die in Curaçao worden verricht aan niet-verbonden beleggingsinstellingen en hun beheerders.

De aangewezen activiteiten komen overigens alleen voor het verlaagde tarief in aanmerking als sprake is van een reële aanwezigheid (op Curaçao), ook wel 'substance' genoemd (art. 1C LWB 1940).

\subsubsection{Substance}

Hoewel het de belastingplichtige in beginsel vrijstaat om de meest optimale fiscale positie te creëren, dient diens handelen niettemin te worden begrensd om oneigenlijk gebruik van de fiscale regeling te voorkomen. In de strijd tegen belastingontwijking heeft Curaçao - in lijn met de OESO- en EU-standaarden - voorwaarden gesteld voor toegang tot de preferentiële regimes in de vorm van antimisbruikbepalingen. Daarbij zijn de Nederlandse regels richtinggevend geweest, waar onder meer aansluiting is gezocht bij het leerstuk 'misbruik van recht'. ${ }^{15}$ Dit leerstuk dat door het Hof van Justitie van de Europese Unie (HvJ EU) is ontwikkeld en oorspronkelijk voor de indirecte belastingen van toepassing was, heeft in de loop der jaren een steeds bredere werking gekregen.

De vraag komt op hoe in de praktijk invulling moet worden gegeven aan het begrip 'substance'. Dit is niet eenvoudig. In het verleden speelde dit begrip een essentiële rol bij het bepalen van het heffingsrecht van een jurisdictie. De laatste jaren is substance veeleer een voorwaarde om gebruik te mogen maken van fiscale (preferentiële) regimes en in voorkomende gevallen van belastingverdragen. ${ }^{16}$ In de kern spitsen de door Curaçao geïmplementeerde substance-voorwaarden zich toe op twee elementen: voldoende feitelijke activiteiten en de aanwezigheid van de feitelijke leiding. De eis van reële aanwezigheid is verwoord in artikel 1C LWB 1940. Onder reële aanwezigheid wordt volgens dit artikel verstaan: '(...) een lichaam dan wel voor zover dat lichaam een concern vormt met een of meer in Curaçao gevestigde lichamen, het concern, dat de inkomsten genererende activiteiten verricht en dat:

a een bij de aard en omvang van de activiteiten van het lichaam dan wel het concern passend aantal gekwalificeerde lokale voltijd werknemers, al dan niet in dienstbetrekking heeft; en

b een bij de aard en omvang van de activiteiten van het lichaam dan wel het concern passend bedrag aan jaarlijks terugkerende lokale operationele kosten heeft. ${ }^{\prime 7}$

De criteria bij de beoordeling of sprake is van voldoende lokale substance zijn gebaseerd op het al dan niet aanwezig zijn van:

15 HvJ EU 26 februari 2019, gevoegde zaken C-116/16 en C-117/16, ECLI:EU:C:2019:135 (T Danmark en Y Denmark) en HvJ EU 26 februari 2019, gevoegde zaken C-115/16, C-118/16, C-119/16 en C-299/16, ECLI:EU:C: 2019:134 (N Luxembourg 1 e.a.).

16 B. Larking, 'A Matter of Substance', Tax Notes International, 22 januari 2018, p. 329-333.

17 Art. 1C lid 1 LWB 1940. 
1 voldoende en ter zake deskundig personeel om de activiteiten van het lichaam te kunnen verrichten en hier toezicht op te houden;

2 een passend niveau van lokale kosten, dat aansluit bij de omvang van de activiteiten van het lichaam.

De essentiële activiteiten van de vennootschap dienen op Curaçao plaats te vinden. Ingeval diensten buiten Curaçao worden verricht, komt de met deze diensten behaalde winst niet in aanmerking voor het verlaagde winstbelastingtarief van $3 \%$. Het is overigens wel toegestaan deze diensten uit te besteden, op voorwaarde dat ook dit in Curaçao plaatsvindt en daarop voldoende toezicht is. Daarnaast speelt ook een rol in hoeverre de rechtspersoon een zelfstandige functie heeft. De vereiste omvang van de substance is afhankelijk van de omvang van de activiteiten (zogenoemde 'relatieve substance'). Zo vergt een beleggingsinstelling in het algemeen minder substance dan een productieonderneming. Verder is van belang dat het personeel zich in Curaçao bevindt, waardoor de feitelijke leiding ook daadwerkelijk in Curaçao plaatsvindt. Overigens worden professionele dienstverleners die de directie voeren over de dienstverlenende vennootschap uitgesloten van het verlaagde tarief. Hoewel de beoordeling of sprake is van voldoende substance afhankelijk is van de specifieke omstandigheden, zijn in de parlementaire stukken desalniettemin enkele voorbeelden aangehaald. ${ }^{18}$ Volgens de memorie van toelichting wordt voldoende substance aanwezig geacht indien aandelen van het lichaam of diens moedermaatschappij regelmatig verhandeld worden op de beurs van Curaçao (Dutch Caribbean Securities Exchange).

\subsubsection{Kwaliteit en kwantiteit van de substance}

Over het algemeen zijn er bij het invullen van het begrip 'substance' twee keuzes: een kwalitatieve benadering en een kwantitatieve benadering. Bij een kwalitatieve benadering gaat het om indicaties als 'effectieve', 'substantiële', 'in overwegende mate' aanwezig zijn van de activiteit. Een kwantitatieve benadering omvat meer objectieve elementen. Volgens de toelichting bij de Ministeriële regeling reële aanwezigheid van 10 september 2019 is het geven van richtlijnen voor de kwantiteit van de substance lastiger. ${ }^{19}$ Volgens genoemde ministeriële regeling dient de omvang van de activiteiten in verhouding te staan tot de hoeveelheid werkgelegenheid die voor deze activiteiten noodzakelijk is, en niet tot het aantal personen dat al dan niet parttime in dienst is genomen of wordt ingehuurd. Dit is een kwantitatieve benadering die evenwel ook kwalitatief nader ingevuld moet worden: de vereiste expertise van deze professionals. Hoewel het op zich geen bezwaar oplevert indien bepaalde activiteiten aan dienstverleners in het buitenland worden uitbesteed, zal dit niet bijdragen aan voldoende lokale substance. Om aan de eis van lokale substance te voldoen, zou volgens de ministeriele regeling in elk geval sprake moeten zijn van voldoende lokale werkzaamheden, in loondienst bij het bedrijf of ingehuurd van lokale derden. Op 23 juli 2020 is deze ministeriële regeling ingetrokken. ${ }^{20}$ Blijkens de toelichting is de Ministeriële regeling reële aanwezigheid, vooruitlopend op de volgende bijeenkomst van het Forum for

18 Staten van Curaçao, zittingsjaar 2017/18, MvT, nr. 3, artikelsgewijze toelichting, artikel I, onderdeel D, p. 14.

19 Ministeriële regeling met algemene werking, 10 september 2019, ter uitvoering van artikel 1C, lid 2, LWB 1940, PB 2019 nr. 56.

20 Ministeriële regeling met algemene werking, 23 juli 2020, ter intrekking van de Ministeriele regeling reële aanwezigheid, PB 2020, nr. 77. 
Harmful Tax Practices (FHTP), ter beoordeling aan het secretariaat van het FHTP voorgelegd. Uit deze beoordeling is gebleken dat de bepalingen van de ministeriële regeling niet duidelijk zijn en verwarring kunnen scheppen ten aanzien van de juiste invulling van lokale reële aanwezigheid. Om een negatief oordeel van het FHTP te voorkomen, is nu besloten om de ministeriële regeling per omgaande in te trekken. Een eventuele nieuwe Ministeriele regeling reële aanwezigheid zal, volgens de toelichting, in nauwe samenwerking met het FHTP plaatsvinden.

\subsection{Belastingfaciliteiten grote projecten}

Curaçao kent sinds lange tijd diverse fiscale faciliteiten om investeringen te stimuleren voor specifieke bedrijven en sectoren, zoals de export, nieuwe industrieën, hotels, vrijezonemaatschappijen en grondontwikkelingsmaatschappijen. ${ }^{21}$ De voordelen zijn onder meer: vrijstelling van de onroerendezaakbelasting, een gematigd winstbelastingtarief van $2 \%^{22}$ voor een beperkt aantal jaren, vrijstelling van invoerrechten voor materialen, goederen en bedrijfsmiddelen, vrijstelling van inkomstenbelasting op uitgekeerde dividenden en andere winstuitkeringen aan aandeelhouders. Er gelden stringente voorwaarden en een minimaal investeringsbedrag van NAf 1 miljoen voor industrie en Naf 2 miljoen voor hotel en grondontwikkeling. ${ }^{23}$ Daarnaast is vereist dat minimaal vijf lokale werknemers in dienst zijn. Met name ondernemers in de toeristische sector hebben veelvuldig van deze faciliteiten gebruik kunnen maken. In 2017 zijn de belastingfaciliteiten samengevoegd in de 'Landsverordening belastingfaciliteiten investeringen' waar het aantal sectoren fors was uitgebreid. In het kader van de belastingherziening 2019 is de 'Belastingfaciliteiten Investeringen' wederom uitgebreid met nog een zevental sectoren: bosbouw, mijnbouw en delfstoffen, winning en distributie van water, rioolsysteem, afvalverwerking en sanering (herstel), groot- en kleinhandel, reparatie van motorvoertuigen en motorfietsen, maatschappelijke dienstverlening, cultuur, sport en recreatie. ${ }^{24}$ De voorwaarden om van de regeling gebruik te maken zijn daarentegen verder aangescherpt. Het minimale investeringsbedrag om toegang te krijgen tot de belastingfaciliteiten is verhoogd naar Naf 5 miljoen voor zowel industrie als voor hotel en grondontwikkeling, waarbij de minimale werkgelegenheidseis is verhoogd van vijf naar tien personen. Hierdoor zullen kleine investeringsprojecten niet langer gebruik van de regeling kunnen maken. De onderbouwing van de gemaakte keuzes blijkt overigens niet uit de parlementaire stukken. Voor de vrijstelling van onroerendezaakbelasting en het verlaagde winstbelastingtarief is met ingang van 1 januari 2020 een minimale investering vereist van Naf 10 miljoen. ${ }^{25}$

Nieuw is dat de faciliteit alleen van toepassing is voor de bv of nv. Het is niet langer vereist dat de vennootschap op Curaçao is opgericht, zolang de buitenlandse rechtsvorm vergelijkbaar is met de bv of nv. Het winstbelastingtarief Belastingfaciliteiten Investeringen is verhoogd van $2 \%$ naar $3 \%$ om een gelijkluidend winstbelastingtarief te heffen als het

21 Zie ook D. Cijntje, Belastingen in de Nederlandse Antillen. Belastingheffing en fiscale faciliteiten in het bijzonder ten aanzien van de Antilliaanse vennootschap, Deventer: Kluwer 1990, p. 72-79.

22 Het verlaagde tarief winstbelasting voor Belastingfaciliteiten Investeringen is per 1 januari 2020 verhoogd van $2 \%$ naar $3 \%$.

23 PB 2016, nr. 77.

24 PB 2018, nr. 84.

25 PB 2018, nr. 92. 
nieuwe preferentiële regime voor specifieke activiteiten. Een ander aspect betreft de voorwaarde dat de belastingplichtige die het verzoek indient, voortaan een onberispelijke fiscale compliancestatus moet hebben. ${ }^{26}$ Het verzoek dient vanaf 1 januari 2020 vergezeld te gaan met een bewijs dat afkomstig is van de Ontvanger, waaruit blijkt dat de belastingplichtige geen direct invorderbare belastingschulden heeft, dan wel een betalingsregeling getroffen heeft.

\section{Effecten preferentiële regimes}

Het is interessant om inzicht te krijgen in de effectiviteit van de nieuwe belastingfaciliteiten en de omvang van de belastingderving die daarmee gemoeid is te onderzoeken. De SER heeft in diens advies over de belastingherziening aangedrongen op een evaluatie van de belastingfaciliteiten. In zijn eerdere advies van augustus 2018 had de SER al aangegeven: 'internationale financiële instituties zijn van mening dat belastingfaciliteiten niet alleen duur zijn in termen van overheidsinkomstenderving en een erosie van de belastinggrondslag, maar dat deze ook nog eens een beperkte impact hebben op de economische groeit. ${ }^{27}$ De Curaçaose regering heeft toegezegd uiterlijk eind december 2021 aan de Staten een verslag te doen toekomen

'over de doeltreffendheid en de effecten van de belastingfaciliteiten opgenomen in de Landsverordening belastingfaciliteiten investeringen, waaronder in ieder geval de budgettaire effecten, economische groei-effecten en effecten op de werkgelegenheid, binnenlandse investeringen, belastingbasis, compliance, crowding out en mogelijke spillover effecten.' 28

Hoewel we dit onderzoek toejuichen, plaatsen wij hierbij toch enige kanttekeningen. Ten eerste is het twijfelachtig of een onderzoek binnen een dergelijk korte periode valide resultaten kan opleveren. Het ligt meer voor de hand om een evaluatie van de belastinguitgave te doen nadat er voldoende tijd is verstreken zodat het instrument tot mogelijke effecten heeft kunnen leiden. Immers, de datagegevens over het gebruik van een faciliteit zijn pas na enige tijd beschikbaar. Een tweede punt betreft de complexe aard van dergelijk onderzoek. Uit een onderzoek (2018) van Tax Justice Network blijkt dat de effectiviteit van belastingfaciliteiten afhankelijk is van een viertal factoren: type faciliteit (winstvrijstelling of kostenaftrek), de duur van de faciliteit (tijdelijk of permanent), de locatie van de activiteiten (e-zones of onbegrensd) en de omvang van de aangeboden faciliteit (volledige vrijstelling of kostenaftrek). ${ }^{29}$ Dit onderzoek van Tax Justice Network is gebaseerd op een analyse van de belastingfaciliteiten van vijftien landen, waaronder tien Europese en vijf Afrikaanse landen. Bij een vergelijking tussen de Europese en de Afrikaanse faciliteiten wordt duidelijk dat Afrikaanse jurisdicties voornamelijk belastingfaciliteiten aanbieden in de vorm van

SER Curaçao, Advies inzake het conceptlandsbesluit, houdende algemene maatregelen, ter uitvoering van artikel 1, lid 7, van de Landsverordening belastingfaciliteiten investeringen, ref.nr. 105/2018-SER, p. 5.

Art. IX lid 1 Landsverordening belastingherziening 2019.

M. Meinzer e.a., Comparing tax incentives across jurisdictions: a pilot study, Tax Justice Network, 3 januari 2019. 
winstvrijstellingen, zoals tax holidays en e-zones. Europese landen bieden daarentegen vooral faciliteiten in de kostensfeer: vervroegde afschrijvingen, aftrek van R\&D-kosten, belastingkortingen en belastingsubsidies voor kapitaalinvesteringen. Volgens Tax Justice Network is het lastig om een goede vergelijking te maken omdat belastingfaciliteiten doorgaans geïntegreerd zijn in complexe regelgeving die mede de belastinggrondslag bepalen.

\section{Afronding}

Met de wijzigingen die Curaçao met het in dit artikel besproken pakket heeft doorgevoerd is in elk geval bereikt dat in de internationale fiscale omgeving Curaçao geheel compliant is. Het staat niet op grijze of zwarte lijsten en wordt dus als een volwaardig fiscaal land beschouwd. Dat is een belangrijke stap. Maar daarmee is niet alles gezegd. Er zijn nog volop uitdagingen om het belastingstelsel op allerlei fronten te verbeteren en meer in overeenstemming te brengen met de huidige economische en maatschappelijke ontwikkelingen. Daarbij moet ook de uitvoering bepaald aandacht krijgen. Maar daarenboven is het ons inziens van groot belang dat Curaçao echt werk maakt van het sluiten van belastingverdragen met landen die er voor Curaçao toe doen. In het verleden was dat wellicht lastig omdat het niet als een land met een volwaardig fiscaal stelsel te boek stond, maar met de nu gemaakte stappen is dat bezwaar van tafel. Belastingverdragen leveren in het algemeen een stevige impuls op voor de economische ontwikkeling.

Wat betreft het binnenlandse stelsel zou eigenlijk een grondig onderzoek moeten worden gedaan. Dat is intensief. En de vraag is of het ook noodzakelijk is. Het afgelopen jaar heeft het Internationaal Monetair Fonds een uitvoerige analyse uitgevoerd naar de economie en de fiscaliteit en ongetwijfeld goede aanbevelingen gedaan. En daarnaast is het wellicht zinvol om de vele aanbevelingen die in Nederland zijn opgenomen in de recente Bouwstenennotitie (mei 2020) eens te bekijken. Daar zitten stellig ideeën tussen die ook voor Curaçao interessant zijn, uiteraard met inachtneming van het eigen karakter van de maatschappij, de economie en het karakter van het land. 